\title{
Determinants of Profitability of Indigenous Chickens in Swaziland
}

\author{
Bongani J. Siyaya
}

P.O. Box 4305, Manzini, M200, Swaziland

\author{
Micah B. Masuku (Corresponding Author) \\ Department of Agricultural Economics and Management \\ P. O. Luyengo, Luyengo. M205. University of Swaziland, Swaziland \\ Tel: 268-7602-6557Ｅ-mail: mbmasuku@uniswa.sz
}

Received: September 29, 2013 Accepted: October 15, 2013
doi:10.5296/ber.v3i2.4346 $\quad$ URL: http://dx.doi.org/10.5296/ber.v3i2.4346

\begin{abstract}
As a move towards ensuring food security and income generation, the Ministry of Agriculture advocates for the commercialisation of indigenous chickens. In 2008, the ministry embarked on a commercialisation training programme. The main purpose of the study was to conduct an economic analysis of the indigenous chickens' production in Swaziland, as well as factors affecting profitability of indigenous chickens' production. Using a stratified random sampling technique, the study used primary data from a sample of 147 smallholder poultry farmers who have been trained by poultry officers on indigenous poultry production in the four regions of Swaziland. A cost - benefit analysis was used to determine profitability and the Cobb Douglas production function was used to identify factors affecting profitability of indigenous chickens. The results revealed an adjusted $\mathrm{R}^{2}$ of 0.85 , hence the variables in the model explained $85 \%$ of the variation in profitability. The results further showed that profitability of indigenous chickens was E0.40 per E1.00 of feed costs. Feed cost, market price, stock size, number of birds sold and number of birds consumed significantly $(\mathrm{p}<0.10)$ affected profitability.. It is recommended that farmers organize themselves to take advantage of discounts when purchasing feed. The Swaziland Government need to construct a hatchery, mini - abattoir and storage facilities per region to improve the production of indigenous chickens. The hatcheries can allow farmers to use incubators to improve hatchability. Farmers can also use the abattoirs to slaughter and dress their chickens and then store them in cold storage for sale. Research on market size and spread should be undertaken to determine the demand patterns of indigenous
\end{abstract}


chickens.

Keywords: Commercialisation, Indigenous chickens, Profitability, Poultry production.

\section{Introduction}

\subsection{Agricultural Production in Swaziland}

Agriculture is traditionally the backbone of Swaziland's economy and a major source of employment for rural households with over $70 \%$ of the population relying on this sector for their incomes. The diverse agricultural activities that take place in the country include the production of sugarcane, citrus fruits, and maize, cotton, forestry and livestock. Swaziland's agricultural sector is divided into two sub-sectors namely; formal and informal or subsistence. Subsistence farming is mainly practiced on Swazi Nation Land (SNL), which is about 60 percent of land on Swaziland (MOA, 2012). It is acquired in terms of Swazi law and custom. While agricultural activities in these areas may be carried out for subsistence purposes, efforts are made to encourage SNL farmers to practice commercial farming (Thompson, 2012). According to Thompson (2012) the formal agriculture embraces the large sugarcane and citrus estates, forestry and other undertakings on individual tenure farms (ITFs), which generate foreign exchange earnings. It covers about 40 percent of the land in Swaziland.

\subsection{Indigenous Poultry Production}

The Ministry of Agriculture (MOA) promotes poultry production and emphasises on broiler production, egg production and the production of indigenous chickens. The MOA (2012) reported that indigenous poultry production is a fast growing industry in the country. The indigenous poultry farmers have been encouraged to commercialise in order to improve their livelihoods in terms of food security, poverty alleviation, income generation and as a drive towards self-sufficiency in poultry and poultry products. According to Thompson (2012) the livestock development policy emphasises the commercialisation of cattle, poultry and pigs in particular, as well as goats in order to create employment and attain food security in the rural areas.

The most common type of poultry kept in rural households is chicken (Gallus domesticus) species (Masuku, 2011). Many farmers keep chickens for meat consumption purposes. In the past chickens were exposed to scavenging systems for feed and had minimal supplementary feed. There was no provision for housing, thus they were characterized by low input and low output. Masimula (2004) noted that surveys indicated that $91 \%$ of families in rural areas of Swaziland raise chickens. In Swaziland, indigenous chickens are kept through subsistence farming practices by almost all the households, with a minimum of at least five birds per family (Thwala, 2012). Like in other developing countries, Swazi farmers use family labour and occasionally use commercially available feeds. The chickens are kept under scavenging production systems with limited application of management interventions to improve productivity. Thwala (2012) argued that indigenous poultry production is of great importance to smallholder farmers, but they face the challenge of improving productivity of their flock which could have financial benefit and promote food security as well as achieve market potential. 
Currently, consumers opt for organically produced meat from indigenous chickens (Ondwasy et al., 2006) than meat from broiler chickens. The demand for exotic chickens is declining worldwide due to a majority of the consumers opting of meat for indigenous chickens. According to Ondwasy et al. (2006), commercialisation of indigenous poultry production is therefore timely in terms of meeting the unmet market demand. Commercial indigenous poultry production is a fast supplementary income-generating enterprise for rural farmers. Though, there are opportunities for exports of indigenous poultry products, the traditional poultry marketing channels need to be clearly defined (Thwala, 2012). Indigenous chickens are ready for marketing at six to eight months and they do not require high financial and technical inputs. There is no formal or organized market for indigenous chickens and as a result, farmers of indigenous chickens compete unfairly with broiler chicken farmers, thus forcing indigenous chicken farmers to lower their prices. However, the demand for indigenous chickens is still high. Many restaurants and food outlets now serve indigenous chicken meat though, only in limited amounts (MOA, 2012).

\subsection{Profitability of Agricultural Produce}

The Agricultural Marketing Resource Centre (AMRC) (2013), on its analysis of agriculture and rural development defined profit as the excess of income over costs. Profitability was described as the measure of the returns a business creates after deducting operating costs and other expenses from income divided by inputs. Though determining profitability may be the most challenging task, it is also a very rewarding part of a new agricultural enterprise. The use of the income statement and sensitivity analysis helps to determine profitability of an enterprise. An income statement measures profitability by recording the costs of production and the value of production for a set period of time, usually a year (AMRC, 2013).

Chase (2008) noted that producers often try to maximize their income by selling produce directly to consumers through various marketing outlets where the highest price of the product can be received. Even though this strategy may allow producers to achieve the highest gross revenue, it may not yield the highest profit because of the differences in transaction costs. According to Chase (2008), products are generally priced based on customers demand competition and costs. Most farmers use the cost based strategy, which is the strategy that determines profit based on cost. This also requires a budget to be developed for each product that contributes to the overall profitability of the business. The budget needs to include all costs of production and transaction costs from the farm or business. Secondly, the profit margin or percentage should be added to help cover family living and other overhead costs.

\subsection{Factors Affecting Profitability of Indigenous Chickens}

Natukunda, Kugonza and Kyarisiima (2011) in their study to determine factors affecting marketing and profitability of indigenous chickens in Uganda used a two stage sampling involving purposive random sampling technique to select 100 chicken farmer households. In the study, they found that indigenous chickens were profitable and profit was found to be 5000 Ugandan shillings (UShs) per bird sold. The factors that affected profitability were: total average costs; distance to the nearest market; access to extension services; education level and experience of the farmer (Natakunda et al., 2011). 
Hossen (2010) conducted a study on the effect of management interventions on the productivity and profitability of indigenous chickens in Bangladesh. It was found that households earn a minimum profit of US\$ 47.3 per annum. It was also noted that with the management interventions such as chick separation and creep feeding of chicks, egg production was increased and mortality of local chickens was reduced. This resulted in the increase of the family or household income from US\$ 47.3 to US\$ 342 per annum. Hossen (2010) further concluded that weaning of chicks, feed supplementation of broody hens during incubation and the creep feeding system of management may have formed a basis of the increasing egg production and survival of the indigenous chickens, which eventually leads to enhanced productivity and profitability of family poultry in Bangladesh.

Dutta, Islam and Kabir (2013) investigated the production performance of indigenous chickens in selected areas of Rajshali, in Bangladesh, using a stratified random sampling technique from six districts. In their study, profitability was calculated using a cost-benefit ratio and it was estimated at US\$ 0.24 and US\$ 0.19 per family and per bird respectively (Dutta et al., 2013). It was concluded that raising indigenous chickens was a feasible and efficient enterprise, which required better understanding of the socio-economic aspects of the small scale poultry farmers in urban, semi-urban and rural areas of Bangladesh.

Debbie Cutting, Technoserve Director (Swazi Observer, 31 July 2012) in a study of the key market dynamics and profit drivers of the indigenous chickens industry in Swaziland, noted that profitability was affected by four key drivers, namely: vaccination costs, transportation costs, costs of supplementary feed and the selling price per unit of an indigenous chicken. She also pointed out that these key drivers vary from one farmer to the other. She emphasised that overspending on supplementary feed eroded more than $50 \%$ of the revenue generated by the producers and more than $25 \%$ of the revenue were spent on transport costs (Swazi Observer, 31 July 2012).

\subsection{Statement of the Problem}

Sohngwe (2009) reported that farmers who are producing village chickens commercially in Swaziland were happy with the profit margins they get when selling their chickens. The demand for organic food and village chickens produced organically was reportedly high. Due to the limited supply of village chickens in the market, consumers would pay a premium for them. Whenever available, the catering industry and supermarkets were failing to get suppliers of village chickens in Swaziland and were unable to satisfy customer demand. Indigenous chicken production in Swaziland offers prospective and current chicken producers and entrepreneurs good business opportunities. Indigenous chicken production also offers the small-scale chicken producers an escape route from the congested and highly competitive broiler production business in Swaziland. Furthermore, Dlamini (2012), the Minister of Agriculture, as quoted by the Swazi Observer (June 8, 2012), noted that most small-holder indigenous poultry farmers were commercialising the industry. He further noted that this was one endeavor to mitigate food insecurity in the country and to create wealth for the farmers themselves as indigenous chickens tend to generate more revenue. However, what is still uncertain is the profitability of indigenous chickens and the factors affecting their profitability. 
1.6 Objectives of the study

The purpose of the study was to assess the economic performance of indigenous chickens reared by smallholder farmers in Swaziland. The specific objectives of the study were to: (1) Characterise indigenous poultry farmers; (2) Determine the profitability of indigenous chickens; and (3) Identify factors affecting profitability of indigenous chickens.

\section{Research Methodology}

\subsection{Research Design}

The study involved a descriptive research using quantitative approaches. It sought to determine the profitability of indigenous chickens and further identify factors affecting their profitability.

\subsection{Sampling and Data Collection}

The target population for the study was active smallholder farmers of indigenous chickens in Swaziland that had been trained by poultry officers on the commercialisation programme between 2009 and 2011. From the population of 729 farmers obtained from a list of farmers trained on the commercialisation programme in the four regions of Swaziland, 147 farmers were sampled using stratified random sampling technique. Data were collected using personal interviews by an aid of structured questionnaire.

\subsection{Data Analysis}

Data were analysed using STATA version 10 software. The profitability of indigenous chickens was analysed using descriptive statistics (means, standard deviation, minimum and maximum values). The Cobb Douglas regression was used to analyse the factors affecting profitability of indigenous chickens.

\subsection{Analytical Framework}

Profitability of the indigenous chickens industry was determined as a ratio of profit to total feed costs. This is because feed costs are major operational costs in the production of poultry, amounting to about $60 \%$. Thus:

Profitability $=\underline{\text { Output }}$

Input

Hence:

Profitability of Input X $=\underline{\text { Profit }- \text { Input } X}$

Input X

Therefore:

Profitability of Feed cost $=\underline{\text { Profit per year }- \text { Total feed costs per year }}$

Total feed costs per year 


\section{Macrothink

The empirical analysis of profitability of indigenous chickens was based on the estimation of a Cobb-Douglas production function in which both the output and inputs were expressed in logarithmic form. The Cobb-Douglas functional form is widely used to represent the relationship of an output to inputs (Bravo-Ureta \& Pinheiro, 1997). According to Khai and Yabe (2011) there are many functional forms for estimating the physical relationship between inputs and output, but the Cobb-Douglas functional form is preferred to other forms, especially if there are three or more independent variables in the model. The Cobb-Douglas production function was used to explain the relationship between the dependent variable (profitability of indigenous chickens) and explanatory variables (factors affecting profitability) and was stated as follows:

$\mathrm{q}=\mathrm{f}(\mathrm{k}, 1)=\mathrm{Ak}^{\alpha} 1^{\beta}$,

Where $\mathrm{A}, \alpha, \beta$ are constants.

The Cobb-Douglas production function for the profitability of indigenous chickens is defined by the general model, $\mathrm{Y}$, to a given set of resources, $\mathrm{X}$, and other conditional factors are given as follows:

$\mathrm{Y}=\beta_{0} \mathrm{X}_{1}{ }^{\beta 1} \mathrm{X}_{2}{ }^{\beta 2} \mathrm{X}_{3}{ }^{\beta 3} \mathrm{X}_{4}{ }^{\beta 4} \ldots \mathrm{X}_{6}{ }^{\beta 6} \mu^{\mathrm{V}-\mathrm{U}}$

This function is linearised in order to be able to use the least squares estimations, hence the following regression specification:

$\ln Y_{i}=\alpha+\beta_{1} \ln X_{1}+\beta_{2} \ln X_{2}+\beta_{3} \ln X_{3}+\beta_{4} \ln X_{4}+\ldots \ldots \beta_{6} \ln X_{6}+\mu ;$

Where: $Y_{i}=$ Profitability (profit per feed cost) in Emalangeni;

$\mathrm{X}_{1}=$ Total number of chickens produced per year by the farmer (stock size);

$\mathrm{X}_{2}=$ Total number of chickens sold by the farmer per year;

$\mathrm{X}_{3}=$ Total number of chickens consumed by the household per year;

$\mathrm{X}_{4}=$ Market price per unit of chicken;

$\mathrm{X}_{5}=$ Total vaccination costs per year;

$\mathrm{X}_{6}=$ Total costs of feed per farmer in Emalangeni;

$\mu=$ Random error term;

$\beta_{i}=$ coefficients of the independent variables $X_{i}$.

\subsection{Explanation of Variables and A Priori Expectations}

Profitability (Y): This is the dependent variable and it is measured by profit per feed cost. The assumption made is that profitability is determined by the variables on the regression model. Table 1 presents the a priori expectations of the independent variables.

Stock size $\left(\mathrm{X}_{1}\right)$ : Total number of chicken units produced in a year. It is expected to have a significant and positive effect on profitability because the higher the stock size, the higher the 
probability to sell.

Total number of chickens sold $\left(\mathrm{X}_{2}\right)$ : A positive and significant relationship is expected between profitability and number of chickens sold.

Total number of chickens consumed $\left(\mathrm{X}_{3}\right)$ : A negative but significant effect is expected between consumption and profitability.

Market price per bird $\left(\mathrm{X}_{4}\right)$ : This is the average market price of indigenous chicken. Demand for food commodities is inelastic, so a positive relationship between price and profitability is expected.

Vaccination costs $\left(\mathrm{X}_{5}\right)$ : These are costs incurred due to diseases or parasites. They increase total costs and reduce profitability. A negative relationship between vaccination costs and profitability is expected.

Feed costs $\left(\mathrm{X}_{6)}\right)$ : This refers to total feed costs of producing indigenous chickens and major costs of production. A significantly negative relationship between feed costs and profitability is expected.

Table 1. Variables and Expected signs

\begin{tabular}{|l|l|}
\hline Variable & Expected Sign \\
\hline Stock size & + \\
\hline Total number of chickens sold & + \\
\hline Total number of chickens consumed & - \\
\hline Market price per bird & + \\
\hline Vaccination costs & - \\
\hline Feed costs & - \\
\hline
\end{tabular}

\section{Results and Discussion}

\subsection{Characteristics of Respondents}

Table 2 shows the characteristics of respondents according to age, gender, level of formal education and marital status. Of the 147 respondents that were interviewed, $66 \%$ were females and $34 \%$ were males. This is because in most homesteads, males are always at work and not at home and most of the farming activities are done by women. Therefore, the majority of indigenous chickens' farmers were women. Most of the men were those that had retired from work, thus keeping indigenous chickens in order to earn income. The results in Table 2 also show that $26 \%$ of the respondents were farmers who were above 60 years old. This includes the group of farmers who were pensioners, and have retired from employment. Twenty one percent of the respondents were 50 to 59 years old and above, while $27 \%$ had a range of 40 to 49 years old. Twenty four percent of the farmers were aged 30 to 39 years old and only $2 \%$ of the respondents were aged less than 30 years. 
Table 2. Characteristics of Respondents

\begin{tabular}{|l|l|l|}
\hline Variable & Frequency & Percentages \\
\hline Gender & 97 & 66 \\
\hline Males & 50 & 34 \\
\hline Females & \multicolumn{2}{|l|}{} \\
\hline Age & 2 \\
\hline $20-29$ years & 3 & 24 \\
\hline $30-39$ years & 36 & 27 \\
\hline $40-49$ years & 39 & 21 \\
\hline $50-59$ years & 31 & 26 \\
\hline Above 60 years & 38 & 11 \\
\hline Marital Status & \multicolumn{5}{|l|}{} \\
\hline Single & 16 & 75 \\
\hline Married & 110 & 0 \\
\hline Divorced & 0 & 14 \\
\hline Widowed & 21 & 31 \\
\hline Educational Level & 35 \\
\hline Primary & 45 & 24 \\
\hline Secondary & 52 & 3 \\
\hline High School & 35 & 7 \\
\hline Tertiary & 5 & \\
\hline None & 10 & \\
\hline
\end{tabular}

According to the results in Table 2, only $11 \%$ of the respondents were single, while $75 \%$ were married and $14 \%$ were widows. The results show that only $7 \%$ of the respondents did not have formal education, while $31 \%$ of them attended up to primary level of formal education and $35 \%$ reached secondary level. Twenty four percent of the respondents completed high school and $3 \%$ had tertiary education. Table 3 further indicates that the average age of the farmers of indigenous chickens was 49 years. This is because the industry is dominated to a greater extent by adults who are the home owners and most of them are pensioners or retired. The youngest farmer was 28 years old and the oldest was 74 years old. The farming experience of the farmers was 12 years on average, ranging from zero years to 50 years of farming experience.

\subsection{Description of the Variables}

As shown in Table 3, the average household size was 5 persons with a range of 1 person to 11 persons per household. All farmers of indigenous chickens were found on Swazi Nation Land (communal land tenure). The average land size allocated per farmer was 3 hectares (ranging from 0.5 ha to 10 ha). Stock size the previous year (2012) varied from 6 chickens to over 300 chickens with a mean of 71 chickens. The current year stock size showed an overall significant decline to a mean of 41 chickens per farmer due to prevalent challenges, especially the high cost of feed. Losses of chickens due to theft stood at about 4 chickens per farmer and chickens that died due to diseases, predators and weather averaged at 28 chickens per farmer per year. 


\section{MInstitute ${ }^{\text {Mnk }}$}

Business and Economic Research ISSN 2162-4860 2013, Vol. 3, No. 2

Vaccination costs per farmer averaged at E87.16 per year; ranging from zero for subsistence farmers who used locally available medicines to control diseases, and was E505.00 for more commercialised farmers. Almost all of the farmers interviewed provided their chickens with supplementary feed and the average feed cost was at E2459.14 per year. Subsistence farmers spent at least E200 on feed, while commercialised farmers spent E9000.00 on feed per year. The cost of breeding stock (hen and cock) costed E66.00 on average, while the most expensive cock was bought at E200.00. The maximum price for a hen of E120.00 was reported. The average price of a cock was at E78.00, while the average price of a hen was E54.00. The average chicken price at the market was E60.00, with a range of E35.00 to E150 maximum per bird. Flea markets to which farmers sell their chickens were located $22 \mathrm{~km}$ away from the farmers, with a minimum of $1 \mathrm{~km}$ to $95 \mathrm{~km}$ away. Farmers far away from flea markets complained of high transport costs that reduced their returns as they had to hire cars to the flea market.

Table 3. Description of the Variables used in the Study

\begin{tabular}{|l|l|l|l|l|}
\hline Variable & Mean & Std. Dev. & Min & Max \\
\hline Farmer's age (years) & 49.453 & 12.394 & 28 & 74 \\
\hline Farming experience (years) & 12.672 & 10.835 & 1 & 50 \\
\hline Commercial farming exp. (years) & 2.9297 & 2.498 & 0 & 21 \\
\hline Household size (persons) & 5.472 & 2.214 & 1 & 11 \\
\hline Vaccination costs (E) & 87.164 & 98.345 & 0 & 505 \\
\hline & & & & \\
\hline Total land size (ha/farmer) & 2.949 & 1.656 & .5 & 10 \\
\hline Land size used by chickens (ha) & 2.073 & 1.129 & .4 & 6 \\
\hline Land tenure (1for SNL; 2 for TDL) & 1 & 0 & 1 & 2 \\
\hline Supplementary feed (1= yes; $2=$ no) & 1.102 & .303 & 1 & 2 \\
\hline Current stock size (number) & 41.898 & 25.634 & 10 & 115 \\
\hline & & & & \\
\hline Previous years' stock size (number) & 71.266 & 53.154 & 6 & 316 \\
\hline Previous year feed cost (E) & 2459.141 & 1796.683 & 200 & 9000 \\
\hline Off-farm income (1= yes; $2=$ no) & 1.125 & .332 & 1 & 2 \\
\hline Breeding stock price (E) & 65.992 & 30.523 & 0 & 200 \\
\hline Market price (E) & 59.922 & 19.042 & 35 & 150 \\
\hline & & & & \\
\hline Extension service (1 = yes; $2=$ no) & 1.484 & .502 & 1 & 2 \\
\hline Cooperative membership (1= yes; $2=$ no) & 1.3125 & .465 & 1 & 2 \\
\hline Production training (1 = yes or 0 = no) & 1 & .178 & 0 & 1 \\
\hline Flea market distance (Km) & 22.27344 & 15.41485 & 1 & 95 \\
\hline Stolen chickens (Number) & 4.425197 & 6.533819 & 0 & 36 \\
\hline & & & & \\
\hline Mortality of chicken (Number) & 27.89063 & 31.87901 & 0 & 198 \\
\hline Sales rate (percentage proportion) & .3412578 & .2704177 & 0 & 1 \\
\hline
\end{tabular}


Even though most farmers were not working, they had off-farm income from children's support and husbands support as most farmers were found to be women who had no formal employment, but housekeepers. All the farmers agreed that they had received training on indigenous chickens through poultry officers from the regional agricultural offices and from some parastatal organizations such as SWADE. About 50\% of the farmers reported to be receiving extension service in their areas, while the others claimed they never received assistance from extension officers. Most of the respondents were either members of cooperatives or were organised in some way to easily access production training and market information.

\subsection{Profitability of Indigenous Chickens}

The profitability of indigenous poultry production was analysed using descriptive statistics (means, standard deviation, minimum and maximum). These were used to determine viability of the indigenous chickens as a business. Profitability is described as a ratio of returns or income to feed costs. Table 4 presents the results of profitability of indigenous chickens.

The mean total returns were estimated at E3539.96 per year and the mean total costs per year were E2546.31. This shows positive returns from the indigenous chickens industry. The minimum profit figures were negative because most farmers had no or very low sales per year (subsistence farmers). The profit figure shows a positive mean of E993.66 and profitability of E0.40 per bird. This means that for every E1.00 spent on feed which is the primary cost, there is E0.40 return earned by the farmers, which indicates that indigenous chicken farming is a viable and profitable enterprise.

Table 4. Profitability of Indigenous Chickens

\begin{tabular}{|l|l|l|l|l|}
\hline Variables & Mean & Std. Dev. & Min & Max \\
\hline Total returns (E) & 3539.96 & 4314.45 & 0 & 29200 \\
\hline Total costs (E) & 2546.31 & 1848.46 & 200 & 9120 \\
\hline Profit (E) & 993.66 & 3867.45 & -3976 & 25022 \\
\hline Profitability (E) & 0.40 & 4.69 & -2.05 & 38.92 \\
\hline
\end{tabular}

US\$ 1 = E9.80 (July, 2013)

\subsection{Factors Affecting Profitability of Indigenous Chickens}

The Cobb-Douglas production function was used to identify the factors that affect profitability of indigenous poultry production. The results in Table 5 show that the model was able to explain $85 \%$ of the variation in profitability as a result of the independent variables (Adjusted $\mathrm{R}$ - squared $=0.847$ ). This indicates that the model represents a fair goodness of fit between the profitability of indigenous chickens and the explanatory variables. The tabulated $\mathrm{F}$ value is 26.75 at $(6,22)$ degrees of freedom and the calculated $F$ - value is 26.75 and it also explains a significant relationship between profitability and the explanatory variables. 
Table 5. Factors Affecting Profitability of Indigenous Chickens.

\begin{tabular}{|l|l|l|l|l|}
\hline Variable & Coefficient & Std. Err. & t-value & $\mathrm{P}$ - Value \\
\hline & & & & \\
\hline Vaccination costs & -0.39 & 0.242 & -1.59 & 0.126 \\
\hline Feed costs & $-2.18^{* * *}$ & 0.205 & -10.59 & 0.000 \\
\hline Stock size & $1.64 * *$ & 0.581 & 2.82 & 0.010 \\
\hline Market price & $3.37 * * *$ & 0.485 & 6.95 & 0.000 \\
\hline Number of chickens consumed & $0.01^{*}$ & 0.003 & 2.14 & 0.044 \\
\hline Number of chickens sold & $0.50^{*}$ & 0.261 & 1.91 & 0.069 \\
\hline Constant & -2.80 & 0.921 & -3.04 & 0.006 \\
\hline
\end{tabular}

$\mathrm{F}(6,22)=26.75 ;$ Prob $>\mathrm{F}=0.000 ; \mathrm{R}-$ Squared $=0.880 ;$ Adjusted $\mathrm{R}-$ squared $=0.846 ;$

$* * *=$ significant at $1 \% ; * *=$ significant at $5 \% ; *=$ significant at $10 \%$.

The costs of feed and market price were found to be significant $(\mathrm{p}<0.01)$ factors of profitability, whilst costs of vaccination were found to be insignificant. Total feed costs over the year were significantly $(\mathrm{p}<0.01)$ related to profitability. The results show that when feed costs are increased by one percent, profitability declines by $2.18 \%$. This result corresponds to the $a$ priori expectation in relation to feed cost. The results further suggest that there is a significant $(\mathrm{p}<0.01)$ and positive relationship between profitability and market price of chickens as expected. This implies that a one percent increase in price of indigenous chickens amounts to $3.37 \%$ increase in profitability. Food commodities demand is inelastic, so increase in market price does not reduce consumption. The higher the number of chickens sold by the farmer, the greater the returns and the greater the profit earned per farmer given total feed costs. The previous year stock size was found to have a significant $(\mathrm{p}<0.05)$ relationship with profitability. An increase in stock size by $1 \%$ would increase profitability by $1.64 \%$. The higher the number of chickens kept, the more chickens available to sell. When the total number of chickens consumed per year increases by one percent, profitability increases by $0.01 \%$. Though the results show that there is a significant $(p<0.1)$ relationship between consumption and profitability, profitability does not increase when consumption increases. The number of chickens sold was significantly $(\mathrm{p}<0.1)$ related to profitability. A percentage increase in the number of chickens sold results to 0.5 percent increases in profitability. The result was not expected. The possible reason for such a result could be that chicken consumed are regarded as returns and not as costs.

\section{Conclusions and Recommendations}

\subsection{Conclusions}

The study has shown that indigenous chickens are profitable. Therefore, the null hypothesis that indigenous chickens are not profitable is rejected. The profitability of indigenous chickens was affected by feed cost, previous year stock size, market prize, the number of chickens consumed and number of chickens sold. 


\subsection{Recommendations}

There is a lack of an organized market for indigenous chickens. Further studies should be conducted to determine the market size and potential for indigenous chickens. Demand and consumption patterns also need to be verified statistically to improve profitability of indigenous chickens. In order for farmers to improve profitability, they need to form associations, produce their own feed or buy feed in bulk so that they benefit from discounts associated with buying in bulk. Further studies should also be conducted to identify alternative markets for indigenous chickens.

\section{References}

AMRC. (2013). Agriculture and Rural Development Profitability: Will it Make Profit. Agricultural Marketing and Resource Centre. Alberta, CA. USA. www.agmrc.org/ operating a business/finance/profitability, 16/01/13.

Ary, D., Jacobs, L.C., \& Razavieh, A. (2002). Introduction to Research in Education. Belmont, CA: Wadsworth/Thomson Learning.

Bravo-Ureta, B., \& Pinheiro, A. E. (1997). Technical, economic, and allocative efficiency in peasant farming: evidence from the Dominican Republic. The Developing Economies 35, 48-67. http://dx.doi.org/10.1111/j.1746-1049.1997.tb01186.x

Chase, C. (2008). Pricing for Profit. Agricultural Marketing and Resource Centre. USA. www.cchase@iastate.edu. 18/01/13.

Dornbusch, R., Fischer, S., \& Startz, R. (2008). Macroeconomics. Tenth Edition. McGraw Hill International Edition.

Fowler, F.J. (2002). Survey Research Methods. Thousand Oaks, CA: Sage Publications.

Khai, H. V., \& Yabe, M. (2011). Technical efficiency analysis of rice production in Vietnam. Journal of ISSAAS , 17(1), 135-146.

Hossen, M. J. (2010). Effect of Management Interventions on the Productivity and Profitability of Indigenous Chickens Under Rural Conditions in Bangladesh. www.Irrd.org, 18/01/2013.

Dutta, R. K., Islam, M. S., \& Kabir M. A. (2013). Production Performance of Indigenous Chickens (Gallus domesticus L.) in Selected Areas of Rajshali, Bangladesh. American Journal of Experimental Agriculture 3(2), 308-323.

Magagula, C. (2012). Shaping Swaziland's Response to Food Insecurity: Indigenous Chickens. Techno-serve. Mbabane. Swaziland.

Martey, E., Ramatu, M., \& Kuwornu, J. (2012). Commercialisation of smallholder agriculture in Ghana: A Tobit regression analysis. African Journal of Agricultural Research.7(14), 2131-2141. http://www.academicjournals.org/AJARDOI:10.5897/AJAR11.1743, 15/10/2012.

Masimula, J. M. (2004). Poultry Enterprise Budget and Farmers Perceptions towards the National Agricultural Marketing Board (NAMBOARD). Unpublished Research Project, 
University of Swaziland.

Masuku, M. B. (2011). An Analysis of the Broiler Supply Chain in Swaziland: A Case Study of the Manzini Region. Asian Journal of Agricultural Sciences, 3(6), 492-499.

MOA (2012). Ministry of Agriculture Annual Report. Introduction to Indigenous Poultry Keeping - The Case of the Swazi Chicken. Mbabane, Swaziland.

Natukunda, K, Kugonza D. R., \& Kyarisiima C. C. (2011). Indigenous chickens of the Kamuli Plains in Uganda: II Factors affecting their marketing and profitability. Livestock Research for Rural Development. 23, Article \#221, http://www.lrrd.org/lrrd23/10/natu23221.htm, $17 / 10 / 2013$

Ondwasy, H., Wesong, H., \& Okitoi, L. (2006). Indigenous Chicken Production Manual. Technical Note Series Number 18. Kenya Agricultural Research Institute. www.kari.org, 21/09/2012,.

Snyder, C., \& Nicholson, W. (2008). Microeconomic Theory: Basic Principles and Extensions. Tenth Ed. International Student Edition, South-Western Cengage Learning, Mason.

Thompson, C. F. (2012) Swaziland Business Year Book. Government of Swaziland. Mbabane. Swaziland. www.swazibusiness.com, 03/10/2012.

Shongwe, S. (2009). High Demand for Village Chickens.. Livestock and Technical Services. Ministry of Agriculture. Mbabane. Swaziland., Times of Swaziland, 24 June, 2009. Accessed from www.times.co.sz, 21/09/2012.

Thwala, M. (2012). Analysing the value chain of the Family Poultry Subsector in the Lower Usuthu Project Area in Swaziland. SWADE. Siphofaneni. Swaziland.

Von Braun, J., Bouis, H., \& Kennedy, E. (1994). Conceptual Framework, In: Agricultural Commercialisation, Economic Development and Nutrition. In Von Braun and Kennedy (eds). The Johns Hopkins University Press, London. England.

\section{Copyright Disclaimer}

Copyright reserved by the author(s).

This article is an open-access article distributed under the terms and conditions of the Creative Commons Attribution license (http://creativecommons.org/licenses/by/3.0/). 